Mary Kingsley's Travels in West Africa, first published in 1897, has now appeared in a third edition (London: Frank Cass, 1965, 705.) with a new introduction by John E. Flint.

The Story of the Rhodesias and Nyasaland, by A. J. Hanna (London: Faber, I965, 30s.) has been revised for the second edition and brought up to date to the dissolution of the Federation.

Sylvia Leith-Ross's African Women: a Study of the Ibo of Nigeria (London: Routledge and Kegan Paul, 1965, 425.) was first published in 1939.

Catalogue of African Dictionaries, Grammars and Phrase-books

A NEw edition of the Oriental-African Catalogue of Dictionaries, Grammars and Phrase-books, including the Languages of the Americas, first published in 1956, has recently appeared from Bailey Bros. and Swinfen, London. It covers more than 250 languages, listed alphabetically, of which over roo are African languages.

\title{
Church Missionary Society: Temporary Closing of Archives
}

THE Church Missionary Society (6 Salisbury Square, London, E.C. 4) is moving its headquarters to Waterloo in 1966 , and the archives office is now closed to students. It is proposed to reopen the office in October 1966 , when students will be welcome to make use of the improved facilities available. 